\title{
Factors affecting the voluntary intake of food by sheep 6. The effect of monosodium glutamate on the palatability of straw diets by sham-fed and normal animals
}

\author{
BY PABLO E. COLUCCI ${ }^{1}$ AND W. LARRY GROVUM ${ }^{2}$ \\ Departments of ${ }^{1}$ Animal and Poultry Science and ${ }^{2}$ Biomedical Sciences, University of Guelph, \\ Ontario NIG 2W1, Canada
}

(Received 20 June 1991 - Accepted 21 February 1992)

\begin{abstract}
Sheep with oesophageal fistulas were used in sham-feeding experiments to assess how sham intakes were affected by (a) physical form of straw (finely and coarsely ground; ground and pelleted), (b) type of food (straw pellets v. lucerne (Medicago sativa) hay pellets) and (c) additions of monosodium glutamate (MSG) with or without $\mathrm{NaCl}$ to the various straw diets. Normal animals were also fed on diets with and without MSG. Sham intakes of fine-ground loose straw $(25 \mathrm{~g} / 30 \mathrm{~min})$ were markedly less $(P=0.002)$ than those of ground and pelleted straw $(711 \mathrm{~g} / 30 \mathrm{~min})$. However, MSG at $5-40 \mathrm{~g} / \mathrm{kg}$ fine and coarse ground straw increased sham intakes by $146(P=0.04)$ and $164 \%(P=0.01)$ respectively. These findings indicated that the intakes of poor-quality diets can be increased by compacting them or by improving their palatability with MSG, or both. Sham intakes of straw pellets in two experiments were $32(P=0.02)$ and $45 \%(P=0.008)$ of those of lucerne pellets $(436 \mathrm{v} .1366$ and $737 v .1640 \mathrm{~g} / 30 \mathrm{~min})$. However, MSG at $20 \mathrm{~g} / \mathrm{kg}$ straw pellets increased sham intakes from 674 to $1100 \mathrm{~g} / 30 \mathrm{~min}(P=0.05)$. When the MSG was mixed with $\mathrm{NaCl}(20 \mathrm{~g} / \mathrm{kg})$, the intakes of straw pellets were increased from 1089 to $1512 \mathrm{~g} / 30 \mathrm{~min}(P=0.02)$. Thus, the addition of MSG with or without $\mathrm{NaCl}$ increased the intakes of straw pellets. The highest intakes of the straw pellets treated with MSG were similar to those for lucerne pellets. When MSG-treated ammoniated barley straw $(10 \mathrm{~g} / \mathrm{kg})$ was fed to normal sheep, the MSG increased DM intakes by $10 \%(719-789 \mathrm{~g} / \mathrm{d} ; P=0.04)$. MSG sprayed onto grass hay $(10 \mathrm{~g} / \mathrm{kg})$ did not, however, affect daily DM intakes by these sheep. In general, the findings indicate that the intake of straw by ruminants may be increased by compressing it to form pellets or cubes and by adding MSG.
\end{abstract}

Palatability: Monosodium glutamate: Voluntary food intake: Sheep

Various definitions exist for palatability. According to Campling (1970), palatability is the hedonic response of an animal to its food depending on taste, smell, flavour and texture. Church (1971) indicates that palatability is the relish which an animal shows when consuming any given feedstuff or ration. Le Magnen (1985) also explains that the palatability of a food relates not to its sensory properties but to the ingestive response to its properties. Le Magnen (1985) goes on to state that palatability is a continuum and that it is greatly influenced by the internal state (e.g. period of deprivation) and learning. In keeping with the sense that palatability must exclude the post-ingestive effects of the food or constituents added to it, Grovum (1988) and Grovum \& Chapman (1988) have stressed the need of using oesophageal-fistulated sheep to assess the palatability of various dietary additives (ingesta are collected from the fistula and, hence, do not enter the stomach).

The voluntary intake of roughages of moderate quality in ruminants is now thought to be controlled mainly by distension of the reticulum and the cranial sac of the rumen, rather than by distension of the dorsal and ventral sacs of the rumen (Grovum, 1988). Modifications in the quality characteristics of the foods, such as their degradability or 
particle size, and combinations of foods and animal attributes can, however, alter reticulo-rumen throughput for a given level of distension and change the intake capacity of the animal (Grovum, 1988). Nevertheless, both intake and the level of rumen fill in cattle were lower after feeding straw than hay ad lib. (Campling et al. 1961). Moreover, results from experiments with sheep fed on straw and hay suggest that there are different sets of fill levels, either before or after feeding, according to the type of food eaten (Greenhalgh $\&$ Reid, 1971). The animals of Greenhalgh \& Reid (1971), fed on straw, also stopped eating before the limits of their physical capacity were reached; these authors concluded that palatability may have restricted the intakes of the straw. Baumont et al. (1990) also indicated that highly palatable roughages were able to override to some extent the satiety signals due to rumen fill and digesta texture. In spite of these findings, palatability has received little attention in most of the investigations concerning intakes of poor-quality roughages in ruminants. This topic is important because the nutrition of people in developing countries may be improved markedly by improving the utilization and the intakes of poor-quality roughages like rice straw by ruminants.

Various investigators have documented intake responses to monosodium glutamate (MSG) in ruminants. Some potential intake stimulants and depressants which acted by modifying food palatability were studied using sheep with oesophageal fistulas (Grovum \& Chapman, 1988). In these studies the sheep were sham-fed on pelleted lucerne (Medicago sativa) hay to assess the effect of added chemicals representing five different tastes, i.e. sweet (sucrose), sour ( $\mathrm{HCl}$ ), salt ( $\mathrm{NaCl}$ ), bitter (urea) and umami (MSG). MSG at 5-40 g/kg airdried food increased the sham intakes of the lucerne by $16-40 \%$. Research is needed to determine what the intake response would be in oesophageal-fistulated sheep for lowquality roughages treated with MSG. Since some workers could argue rightly that the collection of the ingesta at the neck in fistulated animals precludes the application of such information in the production situation, the effect of MSG on intakes of medium- to lowquality roughages was also determined in normal animals. Previous work with mixed highquality diets in calves (Waldern \& Van Dyk, 1971) and lambs (Galgan \& Russell, 1968) demonstrated positive intake responses to MSG additions to diets. However, no conclusive information is available on the effect of adding MSG to low-quality roughages fed to mature sheep. In addition to studying these issues, the present experiments examine the effect of physical forms of straw on its palatability. A brief report on part of the work has been published (Grovum, 1984).

\section{EXPERIMENTAL}

\section{Sheep, housing and feeding}

Sham-feeding (Expts 1-4). Six mature crossbred Suffolk wethers, from among the same group of animals described by Grovum \& Chapman (1988), were used in Expts 1-4. The sheep were prepared with oesophageal fistulas closed by plugs. A complete description of surgical procedures, plugs and post-operative maintenance was given by Grovum \& Chapman (1988). The sheep weighted $75-80 \mathrm{~kg}$. They were housed in metabolism cages in a temperature-controlled room $\left(20-23^{\circ}\right)$, and provided with continuous lighting and background noise from a radio. Fresh water was available at all times other than during experiments as described later (p. 39). Lucerne hay was given ad lib. as a maintenance diet and mineral blocks were provided except for short periods on experimental days. The lucerne hay contained $(\mathrm{g} / \mathrm{kg}$ dry matter $(\mathrm{DM})$ : crude protein $(\mathrm{N} \times 6.25) 202$, acid-detergent fibre 314, fat 22, ash 66. During the course of the study, the sheep were treated for internal parasites with a broad-spectrum anthelmintic (Tramisol; Cyanamid) and for external parasites with a powder containing malathion. Between experiments the sheep were 
removed from the cages and kept in pens for exercise. Wheat straw in different physical forms was used in short sham-feeding experiments (Expts 1-4) and will be referred to as straw. The straw contained (g/kg DM): crude protein 34 , acid-detergent fibre 516 , fat 14 , ash 37. In Expt 3, the sheep were also fed on ground and pelleted lucerne (a highly palatable food) with a composition similar to the lucerne hay described previously.

Normal feeding (Expts 5 and 6). The six non-fistulated crossbred wethers (approximately 9 months of age) used in Expts 5 and 6 were kept in individual pens bedded with wood shavings for 4 months. The temperature of the room was controlled $\left(20-23^{\circ}\right)$ and the lighting was left on continuously. At the beginning of the experiments the sheep weighed 42.3 (SD 4.7) kg. Before the start of the experiments the animals were treated for parasites with ivermectin (Ivomec; MSDAGVET, Division of Merck Frosst Canada Inc.) and injected intramuscularly with the vitamins retinol and cholecalciferol. The sheep were closely shorn both before and after Expt 5. The grass hay fed in Expt 5 contained (g/ $\mathrm{kg} \mathrm{DM})$ : crude protein 77 , acid-detergent fibre 458 , ash 51 . The ammoniated barley straw fed in Expt 6 contained (g/ $\mathrm{kg} \mathrm{DM})$ : crude protein 65, acid-detergent fibre 547, ash 42.

\section{General experimental protocol}

Sham-feeding (Expts 1-4). The palatability of different forms of straw was assessed by depriving the sheep of food for $5.5 \mathrm{~h}$ to induce hunger and then sham-feeding them for $30 \mathrm{~min}$. On experimental days, the sheep were fed on fresh lucerne hay from 08.00 to 09.00 hours and then deprived of food for $5.5 \mathrm{~h}$. Water was available at all times except during the sham-feeding period. After removing the oesophageal plugs, the sheep were offered weighed amounts of the experimental food over three 10 min feeding periods starting at 14.30 hours. During the sham-feeding period a rubber collection bag was attached over the fistula and secured around the neck to collect ingested food. The amount of the experimental foods offered to individual sheep always exceeded what they could consume during the $30 \mathrm{~min}$ period. Food intakes of air-dried diets were recorded after 10,20 and $30 \mathrm{~min}$ of sham-feeding. However, only the total intake for the three periods was used in the analyses of results. At the end of the experiment the bags were removed, the plugs replaced and the hay, water and the salt blocks returned to the sheep. Before being used in any experiment the sheep were sham-fed on the different experimental foods to accustom them to the experimental technique and to adapt them to the new foods. The experiments were performed daily from Monday to Friday and they were conducted in the following sequence: MSG in fine-ground straw (Expt 1A), fine-ground loose straw $v$. fine-ground and pelleted straw (Expt 2), straw pellets $v$. lucerne pellets (Expt 3A), MSG in straw pellets (Expt 4A), MSG and $\mathrm{NaCl}$ in straw pellets (Expt 4B), straw pellets $v$. lucerne pellets (Expt 3B) and, finally, MSG in coarse-ground straw (Expt 1B).

Normal feeding (Expts 5 and 6 ). In Expts 5 and 6 the animals were individually fed ad lib. (15-20\% refusals). Foods were offered at 09.00 hours daily in individual food trays. Any uneaten food from the previous day was collected and weighed daily before the morning feeding. Representative samples of foods offered and refused were taken daily and pooled samples were analysed for DM content to estimate DM intake.

The MSG used in all experiments was laboratory grade (L-glutamic acid, monosodium salt; Sigma).

\section{Expt 1}

In Expt 1A the purpose was to study how MSG affected sham intakes of fine-ground straw (particle size up to $10 \mathrm{~mm}$ ). The straw was sprayed with an aqueous solution to add 0,5 , 10,20 and $40 \mathrm{~g} \mathrm{MSG} / \mathrm{kg}$ air-dried straw. This was done $24 \mathrm{~h}$ before feeding to allow the food to dry at room temperature. Fresh batches of MSG solution were prepared daily. The 
Table 1. Expts 5 and 6. Levels of various constituents added to grass hay and barley straw ( $\mathrm{g} / \mathrm{kg}$ air-dried material) to produce the treatments used*

\begin{tabular}{llllll}
\hline Treatments... & A & B & C & D \\
\hline Urea & 10 & 10 & - & - \\
MSG & $\overline{20}$ & 10 & $\overline{80}$ & 60 \\
SBM $\ddagger$ & & - & 80 & 60 \\
\hline
\end{tabular}

MSG, monosodium glutamate; SBM, soya-bean meal.

* An aqueous solution $(100 \mathrm{ml})$ of urea, MSG and minerals $\dagger$ provided the required levels of chemicals when added to $1 \mathrm{~kg}$ feed dry matter (DM). Fresh solutions of urea, MSG and minerals were made up daily.

† Supplied (per kg feed DM): $\mathrm{NaCl} 6 \mathrm{~g}, \mathrm{Na}_{2} \mathrm{SO}_{4} 5 \mathrm{~g}, \mathrm{MgSO}_{4} \cdot 7 \mathrm{H}_{2} \mathrm{O} 9 \mathrm{~g}, \mathrm{CoCl} .6 \mathrm{H}_{2} \mathrm{O} 0.08 \mathrm{mg}, \mathrm{MnCl}_{2} \cdot 4 \mathrm{H}_{2} \mathrm{O}$ $7.2 \mathrm{mg}, \mathrm{ZnSO}_{4} .7 \mathrm{H}_{2} \mathrm{O} 5.9 \mathrm{mg}, \mathrm{KI} 0.03 \mathrm{mg}$.

+ SBM was sprinkled onto the top of the food after it was sprayed with the other chemicals. The levels of SBM differed to keep the diets isonitrogenous.

treated straws were sham-fed to five sheep in five successive days according to a $5 \times 5$ Latin square design.

In Expt $1 \mathrm{~B}$ the purpose was to study how MSG, as used in Expt $1 \mathrm{~A}(0,5,10,20$ and $40 \mathrm{~g} / \mathrm{kg}$ straw), affected the $30 \mathrm{~min}$ sham intakes of coarse-ground straw having a particle size up to $30 \mathrm{~mm}$. The experimental design was similar to the one used for Expt 1A.

\section{Expt 2}

The objective of this experiment was to determine the effect of physical form of straw (fineground loose straw $v$. fine-ground and pelleted straw) on the sham intakes of DM. A $6 \times 2$ cross-over design involving six animals and two periods was used.

\section{Expt 3}

In Expt $3 \mathrm{~A}$ the sham intakes of ground and pelleted straw (diameter of the pellets was $4.7 \mathrm{~mm})$ and ground and pelleted lucerne hay $(4.7 \mathrm{~mm}$ pellets) were compared. The foods were sham-fed to six sheep on successive days in a cross-over design.

Expt $3 \mathrm{~A}$ was repeated except that data were available from only five sheep (expt $3 \mathrm{~B}$ ).

\section{Expt 4}

Expt 4A examined how spraying MSG onto finely-ground and pelleted straw affected sham intakes in 30 min periods. A cross-over design with six sheep and two periods was used. The straw pellets were from the batch used in Expts 2 and 3. The pellets were sprayed with an aqueous solution to add $20 \mathrm{~g} \mathrm{MSG} / \mathrm{kg}$ air-dried straw pellets $24 \mathrm{~h}$ before feeding. The treated pellets were left to dry at room temperature before being fed.

Expt 4B was similar to Expt 4A except that both MSG $(20 \mathrm{~g} / \mathrm{kg})$ and $\mathrm{NaCl}(20 \mathrm{~g} / \mathrm{kg})$ were sprayed onto the straw pellets and the experiment involved five sheep on two successive days in a cross-over design.

\section{Expts 5 and 6}

The aim of these experiments was to ascertain whether or not MSG would increase DM intake in normally-fed sheep. Expts 5 and 6 were conducted in sequence with a 1-week interval between experiments.

Expt 5 investigated the effect on voluntary intake of adding MSG, urea and soya-bean meal to a chopped-grass-hay diet. The four treatments described in Table 1 were allocated according to $4 \times 4$ Latin square design with two columns (sheep) added (Cochran \& Cox, 
1957). The length of the experiment was $64 \mathrm{~d}$ (four $16 \mathrm{~d}$ periods). Days $1-10$ of each period were used as an adjustment period. The values for intake for days 11-16 were analysed. To eliminate the possibility that a protein or mineral deficiency in the diet was depressing voluntary food intake, the hay was supplemented with either soya-bean meal or urea and a mineral mix made from laboratory-grade chemicals (Table 1). The four treatments, therefore, consisted of the grass hay supplemented with either urea or soya-bean meal with or without addition of MSG (Table 1). The six wethers used in this experiment were individually fed and offered a daily amount of hay which ensured that there was a refusal of $15-20 \%$ by the end of the $24 \mathrm{~h}$ feeding period. The four different solutions (A, B, C and $D$; Table 1) were sprayed onto the hay at feeding time at the rate of $100 \mathrm{ml} / \mathrm{kg}$ hay in individual large food boxes. Subsequently, the required amount of soya-bean meal was sprinkled on the hay.

Expt 6 examined the effect of MSG on the voluntary intake of ammoniated barley straw supplemented with soya-bean meal. The six wethers used in Expt 5 were randomly allocated to either group 1 or group 2 in a switchback design (Cochran \& Cox, 1957). The length of Expt 6 was $36 \mathrm{~d}$ and it was divided into three $12 \mathrm{~d}$ periods. The two treatments were barley straw sprayed with solution $\mathrm{C}$ from Table 1 (control; C) and barley straw sprayed with solution D (MSG; D). In both cases the levels of soya-bean meal indicated in Table 1 were sprinkled on top of the straw after the solutions were applied. Group 1 (three sheep) received the sequence $C(P 1), D(P 2)$ and $C(P 3)$ whereas group 2 (three sheep) received the sequence D (P1), C (P2) and D (P3). The feeding procedures were as described for Expt 5 . The values for intakes for the last $6 \mathrm{~d}$ of each period were analysed.

\section{Statistical analysis}

Data on 30 min sham intakes of air-dried diets from Expts 1-4 were subjected to statistical analyses. The dose-response data of Expts 1A and 1B were examined by analysis of variance of a $5 \times 5$ Latin square design (SAS, 1981) and the variances due to levels of MSG were resolved into linear and quadratic components. Differences among mean intakes were tested for significance by the protected least significant difference method (Snedecor \& Cochran, 1980). In addition, in each experiment (1A and 1B) the mean of the intakes of the straw only diet was compared with the mean of the intakes for all four levels of MSG (Snedecor \& Cochran, 1980). The sham intake data from Expts 2-4 were subjected to analysis of variance for $6 \times 2($ Expt 2, 3A and 4A) and $5 \times 2$ (Expt 3B and 4B) cross-over designs (Cochran \& Cox, 1957). The intake data of Expt 5 were analysed according to a $4 \times 4$ Latin square with two columns added (four treatments, four periods, six animals) using the general linear models procedure (SAS, 1981). Data from Expt 6 were analysed according to a switchback design using the general linear models procedure (Sanders \& Gaynor, 1987). The model contained variables for animal, period (linear) by animal, period and treatment.

\section{RESULTS}

The spraying of MSG onto fine-ground (Expt 1A) and coarse-ground (Expt 1B) straw resulted in significant increases in intake during the 30 min periods of sham eating (Table 2). The mean effects of MSG (differences between the mean of the intakes for all concentrations of MSG and the mean of the intakes for the control animals) were 42 (SE 18) $\mathrm{g} / 30 \mathrm{~min}(P=0.04)$ in Expt $1 \mathrm{~A}$ and 66 (SE 21) g/30 min $(P=0.01)$ in Expt 1B. A significant quadratic response due to the added amounts of MSG was determined in both Expt $1 \mathrm{~A}$ $(P=0.005)$ and Expt 1B $(P=0.002)$. For fine-ground straw (Expt 1A) the intakes of DM $(Y, \mathrm{~g} / 30 \mathrm{~min})$ predicted from $\mathrm{MSG}$ added $(X, \mathrm{~g} / \mathrm{kg} \mathrm{DM})$ was:

$$
Y=23.5+4.76 X-0.075 X^{2} ; \quad \text { SE of } Y 8.65
$$


Table 2. Expt $1^{*}$. Effect of monosodium glutamate (MSG) on intakes $(\mathrm{g})$ of fine (Expt $\left.1 \mathrm{~A}\right)$ - and coarse (Expt IB) - ground wheat straw by sheep during 30 min sham-feeding after $5.5 \mathrm{~h}$ feed deprivation

\begin{tabular}{lcccccc}
\hline $\begin{array}{l}\text { Concentration levels of MSG } \\
(\mathrm{g} / \mathrm{kg} \text { air-dried straw) ... }\end{array}$ & 0 & 5 & 10 & 20 & 40 & $\begin{array}{r}\text { SE† } \\
(\mathrm{g})\end{array}$ \\
\hline Fine-ground straw & $29^{\mathrm{a}}$ & $35^{\mathrm{a}}$ & $66^{\mathrm{ab}}$ & $91^{\mathrm{b}}$ & $93^{\mathrm{b}}$ & $16 \cdot 6$ \\
Coarse-ground straw & $40^{\mathrm{a}}$ & $61^{\mathrm{a}}$ & $78^{\mathrm{ab}}$ & $129^{\mathrm{bc}}$ & $155^{\mathrm{b}}$ & $19 \cdot 2$ \\
\hline
\end{tabular}

\footnotetext{
$\mathrm{a}, \mathrm{h}, \mathrm{r}$ Mean values in the same horizontal row with different superscript letters differed significantly (Expt $1 \mathrm{~A}$, $P<0.05 ;$ Expt 1B, $P<0.01)$ using the protected least significant difference method.

* For details of procedures, see pp. 39-40.

$\dagger \sqrt{ }($ error mean square $/ 5)$.
}

Table 3. Expts 2-4*. Effect of physical form of straw (Expt 2), of feed (Expt $3 A$ and 3B), of monosodium glutamate (Expt $4 A$ ) and of monosodium glutamate plus sodium chloride (Expt $4 B$ ) on intakes $(g)$ by sheep during 30 min sham-feeding

(The sham-feeding was preceded by $5.5 \mathrm{~h}$ feed deprivation to induce hunger)

\begin{tabular}{|c|c|c|c|c|c|c|}
\hline Expt ${ }^{\dagger}$ & Straw pellets & $\begin{array}{l}\text { Ground } \\
\text { loose } \\
\text { straw }\end{array}$ & $\begin{array}{c}\text { Lucerne } \\
\text { (Medicago sativa) } \\
\text { pellets }\end{array}$ & $\begin{array}{c}\text { Straw pellets }+ \\
\text { MSG }\end{array}$ & $\begin{array}{c}\text { Straw pellets }+ \\
\mathrm{MSG}+\mathrm{NaCl}\end{array}$ & SED \\
\hline 2 & 711 & 25 & - & - & - & 98 \\
\hline $3 \mathrm{~A}$ & 436 & - & 1366 & - & - & 254 \\
\hline $3 B$ & 737 & - & 1640 & - & - & 135 \\
\hline $4 \mathrm{~A}$ & 674 & - & - & 1100 & - & 153 \\
\hline $4 \mathrm{~B}$ & 1089 & - & - & - & 1512 & 96 \\
\hline
\end{tabular}

All differences between diets were significant $(P<0.05$ or $P<0.01)$.

SED, standard error of the difference between two treatment means.

* For details of procedures, see pp. 39-40.

$\dagger$ All the experiments were arranged as cross-over designs; $2,3 \mathrm{~A}$ and $4 \mathrm{~A}$ were 6 (animals) $\times 2$ (treatments) designs and $3 \mathrm{~B}$ and $4 \mathrm{~B}$ were 5 (animals) $\times 2$ (treatments) designs.

The corresponding equation for coarse-ground straw in Expt $1 \mathrm{~B}$ was:

$$
Y=35 \cdot 9+5 \cdot 63 X-0 \cdot 066 X^{2} ; \quad \text { SE of } Y 7 \cdot 81
$$

The sham intakes of air-dried ground loose straw $(25 \mathrm{~g} / 30 \mathrm{~min})$ were markedly less $(P$ $=0.002)$ than those of ground and pelleted straw $(711 \mathrm{~g} / 30 \mathrm{~min}$; Expt 2, Table 3), indicating that some physical attribute of the loose straw was making it either undesirable or difficult to consume rapidly.

The sham intakes of air-dried straw pellets were significantly less than those of lucerne pellets in both Expt 3A $(P=0.02)$ and 3B $(P=0.008)$ (Table 3), indicating that the straw pellets were relatively unpalatable.

Sham intakes of air-dried straw pellets sprayed with MSG alone (Expt 4A) or with MSG and $\mathrm{NaCl}($ Expt 4B) were $1.63(P=0.05)$ and $1.39(P=0.01)$ times greater respectively than the intakes of untreated pellets (Table 3 ). This indicates that the addition of MSG to the straw pellets improved their taste/smell for the sheep.

In the normal sheep the addition of MSG to grass hay (Expt 5) did not have any effect on their voluntary intake of food DM (Table 4). The overall mean DM intake for the four 
Table 4. Expts 5 and $6^{*}$. Mean values for total dry matter intakes $(g / d)$ of chopped hay (Expt 5) and ammoniated barley straw (Expt 6) in normally-fed sheep

\begin{tabular}{ccccccc}
\hline & & Treatments $\uparrow \ldots$ & A & B & C & D \\
Expt & & Urea & Urea +MSG & SBM & SBM +MSG & SED \\
\hline 5 & Hay & 876 & 910 & 896 & 889 & $43 \cdot 9$ \\
6 & Barley straw & - & - & $719^{\mathrm{a}}$ & $789^{\mathrm{b}}$ & $23 \cdot 1$ \\
\hline
\end{tabular}

${ }^{a}, b$ Difference between mean values was significant $(P=0.039)$.

SED, standard error of the difference between two treatment means.

* For details of procedures, see pp. 39-41.

+ For details of treatments, see Table 1.

treatments was 20 (SD 1.39) g/ $\mathrm{kg}$ body-weight. However, MSG significantly increased the intakes of DM from ammoniated barley straw (Expt 6) from 719 to $789 \mathrm{~g} / \mathrm{d}(P=0.04$; Table 4).

\section{DISCUSSION}

The ability of MSG to evoke a distinctive taste sensation is well known (Cagan et al. 1979). The taste is called 'umami' in Japanese, which is translated as 'delicious' or 'savoury' (Cagan et al. 1979). Umami is a taste quality represented by glutamates and 5'-nucleotides (O'Mahony \& Ishii, 1987). Glutamic acid exists in two optical isomers, L- and D-, and as a racemic mixture of the two. Only the monosodium salt of L-glutamic acid exhibits the flavour capacity (Powell, 1968). It is well known that MSG is widely used in cooking as a flavour enhancer. Possible mechanisms for the ability of MSG to stimulate taste receptors have been discussed by Cagan et al. (1979).

The animal factors affecting intakes can be classified into pre- and post-absorptive components. The pre-absorptive factors, including all the oral, pharyngeal and visual sensations arising from the food, were thought by Grovum (1988) and Grovum \& Chapman (1988) to determine its palatability. Those factors operating after the food leaves the mouth were referred to as post-ingestive effects by these authors and included gastrointestinal tract processes and post-absorptive metabolic effects (Mook, 1963). When palatability and post-ingestive effects are separated by sham-feeding the effect of a food treatment (physical or chemical) on intake may be completely different from when the food is consumed normally. This was shown for $\mathrm{NaCl}$ and $\mathrm{HCl}$, for example, by Grovum \& Chapman (1988).

The greater sham intakes of ground and pelleted straw compared with ground loose straw (Expt 2) could be attributed to enhanced palatability due to improved texture or less dust, but one could also argue that the effect was unrelated to palatability and was due simply to compaction. At the moment we have no basis for deciding which interpretation is correct. To progress further in our understanding of this subject we may need to start defining palatability in terms of the number of bar-presses (a measure of motivation) that an animal will make to gain access to food, rather than using sham intakes as the measuring device. For example, if an animal bar-presses more frequently or a greater number of times in total to open a door to eat pelleted straw as opposed to loose chopped straw, this may indicate either that the pellets were more palatable or that the sheep liked the pelleted straw better for various reasons, including learning which is discussed further (p. 44). If this does not occur, one must assume that there is no difference in motivation to eat either of the diets. Consequently, the intake response due to pelleting observed in Expt 2 would be 
interpreted as a simple effect of compaction (no palatability effect involved) because the mouth, pharynges and oesophagus may be considered as a conveyor system and any physical conveyor system of limited capacity could transport more mass $/ \mathrm{min}$ if the material being transported was compacted. Regardless of the biological interpretation of the present results, the net effect of pelleting was increased consumption which is important in any production system. In normal animals, intakes of ground lucerne and ground straw were also increased by pelleting (Meyer et al. 1959; Weir et al. 1959; Dittrich et al. 1981). The pelleting process was thought to convert a fine, dusty food into a more palatable form (Meyer et al. 1959). Van Niekerk et al. (1973) also attributed part of the higher intake of a medium-quality hay offered to sheep in a pelleted form as opposed to a chopped form to improved palatability. The magnitude of the intake response that can be expected from grinding and pelleting seems to be negatively correlated with the quality of the tested material (Minson, 1963), the largest increases being observed with the poorer roughages. Minson's (1963) review may indicate that ruminants find the texture of poor-quality roughages undesirable, because once the structure of the plant material is destroyed by grinding and pelleting one finds a relatively greater intake response with the poor diets compared with the high-quality diets. However, once again caution is needed because we do not know if the animals ate less of the unpelleted poor-quality diets due to them being unpalatable or due to the possibility that the sheep had learned that there was little reward from eating such material. The concept of learning (Matthews \& Kilgour, 1980; Chapple \& Lynch, 1986; Provenza \& Balph, 1988) as a factor controlling intake needs to be investigated further in ruminants. It is well accepted that sheep select against stems and other highly lignified plant parts while grazing or while consuming hay but we really do not know why. Sheep also had a preference for lucerne hay compared with cereal hay (Hutson $\&$ van Mourik 1981). The animals could be selecting for specific nutrients (e.g. protein) or the selection could be a reflection of the higher-quality roughages being more palatable (McClymont, 1967). More research is needed to resolve these basic issues.

The greater sham intakes of lucerne pellets compared with straw pellets (Expt 3A and 3B) suggests that the sheep preferred the taste or smell, or both, of the lucerne pellets.

The use of various dietary flavouring agents has become a common practice in the human food industries and is being used in standard commercial starter rations for baby pigs (MSG) to enhance the flavour of the starter (Gatel \& Guion, 1990). In heifers, inclusion of licorice or molasses significantly increased preference for concentrates with $100 \mathrm{~g}$ added meat-and-bone meal $/ \mathrm{kg}$ (Arave et al. 1989). A commercial flavour agent called Simax 100 (made up of a mixture of caramel, maple syrup, orange oil, vanilla and citronella) has also been reported to increase significantly $(10 \%)$ silage DM intake in lactating dairy cows (Weller \& Phipps, 1989).

The ability of MSG to stimulate sham intakes in sheep has now been demonstrated in both poor- and high-quality diets. The effect of MSG in the present experiments depended on the concentration applied to the straw (Expt 1A and 1B). Additions of up to $20 \mathrm{~g}$ $\mathrm{MSG} / \mathrm{kg}$ straw resulted in successive increases in sham intakes. The intakes of both the fine- and coarse-straw diets at $20 \mathrm{~g} \mathrm{MSG} / \mathrm{kg}$ straw were $3 \cdot 1$ and $3 \cdot 2$ times higher than those for controls respectively. The ratios are admittedly high because of the extremely low control values $(29-40 \mathrm{~g} / 30 \mathrm{~min})$. The actual increases in intakes ranged from 62 to $89 \mathrm{~g} / 30 \mathrm{~min}$. In the work of Grovum \& Chapman (1988) corresponding increases in the intake of lucerne pellets ranged from 333 to $731 \mathrm{~g} / 30 \mathrm{~min}$ (occurred at $10 \mathrm{~g} \mathrm{MSG} / \mathrm{kg}$ ). However, a better comparison may be between the latter findings and the increases in the intakes of straw pellets which amounted to from 423 to $426 \mathrm{~g} / 30 \mathrm{~min}$ in the present experiments (Expt $4 \mathrm{~A}$ and $4 \mathrm{~B}$, using $20 \mathrm{~g} \mathrm{MSG} / \mathrm{kg}$ straw pellets). The MSG improved the palatability of the straw pellets and made them essentially equal in acceptability to 
untreated lucerne pellets. Being able to raise the sham intakes of a poor-quality diet like untreated cereal straw to match the intakes of a high-quality diet like lucerne is significant. The challenge now is to learn how to apply such basic knowledge to improve the productivity of normal ruminants fed on poor-quality diets that have been treated to improve their digestibilities.

A number of responses to MSG have been documented. Weanling calves, beginning at 3 weeks of age, selected more of a flavoured diet containing $2 \mathrm{~g} \mathrm{MSG} / \mathrm{kg}$ than a nonflavoured diet (Waldern \& Van Dyk, 1971). Lambs, beginning at $18 \mathrm{~d}$ of age, also ate more of a high-concentrate diet containing $5 \mathrm{~g} \mathrm{MSG} / \mathrm{kg}$ than an untreated diet (Galgan \& Russell, 1968). In another experiment the addition of $5 \mathrm{~g} \mathrm{MSG} / \mathrm{kg}$ ration made up of equal parts of lucerne and concentrates increased both the intakes and live-weight gains of lambs from 90 to $135 \mathrm{~d}$ of age relative to an untreated diet (Galgan \& Russell, 1968). However, in an experiment with sheep fed on ammonia-sulphite-treated straw the addition of $20 \mathrm{~g} \mathrm{MSG} / \mathrm{kg}$ had no effect on either the rate of eating or the total daily consumption (G. Dryden, personal communication). In the normal animals in the present investigations the lack of an intake response observed when MSG and $\mathrm{NaCl}$ were added together to chopped grass hay (Expt 5) cannot be explained. However, the higher intakes of the MSG-treated ammoniated barley straw relative to the control diet (Expt 6) can be attributed to an increase in palatability. An effect of MSG on the ruminal environment by providing extra $\mathrm{N}$ (could indirectly affect intake) can be ruled out since the untreated straw was supplemented with $20 \mathrm{~g}$ extra soya-bean meal (provided an equivalent amount of $\mathrm{N}$ ). The moderate intake response to the MSG (10\% increase) was comparable with the results obtained with lactating dairy cows fed on grass silage treated with flavouring agents (Weller \& Phipps, 1989).

There are several areas in which intake stimulants could have potential practical use. One is in the treatment of low- to medium-quality roughages, such as cereal straws, maize residues (stover) and medium-quality hays or silages, that have previously been improved by physical or chemical treatments to increase intake and support moderate levels of production. The second potential use is with high-quality diets fed to high-yielding dairy cows in early lactation when the nutrient requirements to support milk production are not usually matched with the amount of food that the animals are able to eat. In this situation intake stimulants could be of great importance, particularly with first-lactating heifers. Intake stimulants could also be useful to overcome or minimize practical problems such as (a) the reluctance of ruminants to eat either new foods or the same food offered in a new form, (b) masking disagreeable tastes or smells arising from food additives (urea) or from concentrates and (c) inducing eating in unfavourable circumstances such as when ruminants are being shipped for long distances and are being rested or adapted to new environments (McDonald et al. 1988). If ruminants can be induced to eat more in transit or on arrival they may be less subject to shipping-related diseases because physical and environmental stressors together with starvation or poor nutrition can depress the immune system (Siegel, 1983). The present work with MSG indicates that it has the potential for increasing the productivity by ruminants.

Skilled technical assistance was provided by Warren Bignell. Funding was provided by the National Sciences and Engineering Research Council of Canada (Grant A2377) and by the Ontario Ministry of Agriculture and Food.

Arave, C. W., Purcell, D. \& Engstrom, M. (1989). Effect of feed flavors on improving choice for a ten percent meat and bone meal dairy concentrate. Journal of Dairy Science 72, Suppl. 1, 563. 
Baumont, N., Seguier, N. \& Dulphy, J. P. (1990). Rumen fill, forage palatability and alimentary behaviour in sheep. Joturnal of Agricultural Science, Cambridge 115, 277-284.

Cagan, R. H., Torii, K. \& Kare, M. R. (1979). Biochemical studies of glutamate taste receptors: The synergistic taste effect of $\mathrm{L}$-glutamate and 5 -ribonucleotides. In Glutamic Acid: Advances in Biochemistry and Physiology, pp. 1-9 [L. J. Filer Jr, S. Garattini, M. R. Kare and R. J. Wurtman, editors]. New York: Raven Press.

Campling, R. C. (1970). Physical regulation of voluntary intake. In Physiology of Digestion and Metabolism in the Ruminant, pp. 226-234 [A. T. Phillipson, editor]. Newcastle: Oriel Press.

Campling, R. C., Freer, M. \& Balch, C. C. (1961). Factors affecting the voluntary intake of food by cows. 2 . The relationship between the voluntary intake of roughages, the amount of digesta in the reticulo-rumen, and the rate of disappearance of digesta from the alimentary tract. British Journal of Nutrition 15, 531-540.

Chapple, R. S. \& Lynch, W. L. (1986). Behavioural factors modifying acceptance of supplementary foods by sheep. Research and Development in Agriculture 3, 113-120.

Church, D. C. (1971). Taste, appetite, and regulation of food intake. In Digestive Physiology and Nutrition of Ruminants, vol. 2, pp. 737-762 [D. C. Church, editor]. Corvallis, Oregon: O \& B Books Inc.

Cochran, W. G. \& Cox, G. M. (1957). Experimental Designs, 2nd ed. New York: John Wiley \& Sons, Inc.

Dittrich, A., Hoffmann, M., Schindler, K. \& Viertel, H. (1981). Untersuchungen zur freiwillingen aufnahme von stroh durch mutterschafe bei verschiedenen darbietungsformen (Investigations into the voluntary intake of straw by non-pregnant ewes as influenced by various feeding methods and forms of forage). Archiv für Tierzucht 24, $127-134$.

Galgan, M.W. \& Russell, T. S. (1968). Use of Dyna-Ferm and monosodium glutamate in rations for lambs. Washington Agricultural Experiment Station, College of Agriculture, Bulletin no. 695. Washington State University, Washington.

Gatel, F. \& Guion, P. (1990). Effects of monosodium 1 glutamate on diet palatability and piglet performance during the sucking and weaning periods. Animal Production 50, 365-372.

Greenhalgh, J. F. D. \& Reid, G. W. (1971). Relative palatability to sheep of straw, hay and dried grass. British Journal of Nutrition 26, 107-116.

Grovum, W. L. (1984). Controls over the intake of straw by sheep: effects of form of diet and intake stimulants on sham feeding. Canadian Joumal of Animal Science 64, Suppl., 150-151.

Grovum, W. L. (1988). Appetite, palatability and control of feed intake. In The Ruminant Animal, pp. 202-216 [D. C. Church, editor]. Englewood Cliffs, New Jersey: Prentice Hall.

Grovum, W. L. \& Chapman, H. W. (1988). Factors affecting the voluntary intake of food by sheep. 4. The effect of additives representing the primary tastes on sham intakes by oesophageal-fistulated sheep. British Journal of Nutrition 59, 63-72.

Hutson, G. D. \& van Mourik, S. C. (1981). Food preference of sheep. Australian Journal of Experimental Agriculture and Animal Husbandry 21, 575-582.

Le Magnen, J. (1985). Hunger. New York: Cambridge University Press.

McClymont, G. L. (1967). Selectivity and intake in the grazing ruminant. In Handbook of Physiology, Section 6, Alimentary Canal, vol. 1. Control of Food and Water Intake, pp. 129-137 [C. F. Code, editor]. Washington, DC: American Physiological Society.

McDonald, C. L., Rowe, J. B., Gittins, S. P. \& Smith, J. A. W. (1988). Feed additives for attracting sheep to eat a pelleted diet during assembly for live export. Australian Journal of Experimental Agriculture 28, 719-723.

Matthews, L. R. \& Kilgour, R. (1980). Learning and associated factors in ruminant feeding behaviour. In Digestive Physiology and Metabolism in Ruminants, pp. 123-144 [Y. Ruckebusch and P. Thivend, editors]. Lancaster: MTP Press Ltd.

Meyer, J. H., Weir, W. C., Dobie, J. B. \& Hull, J. L. (1959). Influence of the method of preparation on the feeding value of alfalfa hay. Journal of Animal Science 18, 976-982.

Minson, D. J. (1963). The effect of pelleting and wafering on the feeding value of roughages - a review. Journal of the British Grassland Society 18, 39-44.

Mook, D. G. (1963). Oral and postingestional determinants of the intake of various solutions in rats with oesophageal fistulas. Journal of Comparative Physiology and Psychology 56, 645-659.

O'Mahony, M. \& Ishii, R. (1987). Recent developments in umami research. In Umami: A Basic Taste, pp. 75-93 [Y. Kawamura and M. R. Kare, editors]. New York: Marcel Dekker, Inc.

Powell, R. (1968). Monosodium Glutamate and Glutamic Acid. Chemical Process Review no. 25. Park Ridge, New Jersey: Noyes Development Corporation.

Provenza, F. D. \& Balph, D. F. (1988). Development of dietary choice in livestock on rangelands and its implications for management. Joumal of Animal Science 66, 2356-2368.

Sanders, W. L. \& Gaynor, P. J. (1987). Analysis of switchback data using Statistical Analysis System, Inc. Software. Journal of Dairy Science 70, 2186-2191.

SAS (1981). SAS for Linear Models. A Guide to the Anova and GLM Procedures. Cary, North Carolina: SAS Institute Inc.

Siegel, H. S. (1983). Effects of intensive production methods on livestock health. Agro-Ecosystems 8, 215-230.

Snedecor, G. W. \& Cochran, W. G. (1980). Statistical Methods, 7th ed. Ames: Iowa State University Press.

Van Niekerk, A. I., Greenhalgh, J. F. D. \& Reid, G. W. (1973). Importance of palatability in determining the feed intake of sheep offered chopped and pelleted hay. British Journal of Nutrition 30, 95-105. 
Waldern, D. E. \& Van Dyk, R. D. (1971). Effect of monosodium glutamate in starter rations on feed consumption and performance of early weaned calves. Journal of Dairy Science 54, 262-265.

Weir, W. C., Meyer, J. H., Garret, W. N., Lofgreen, G. P. \& Ittner, N. R. (1959). Chopped rations compared to similar rations fed chopped or ground for steers and lambs. Journal of Animal Science 18, 805-814.

Weller, R. F. \& Phipps, R. H. (1989). Preliminary studies on the effect of flavouring agents on the dry-matter intake of silage by lactating dairy cows. Journal of Agricultural Science, Cambridge 112, 67-71. 